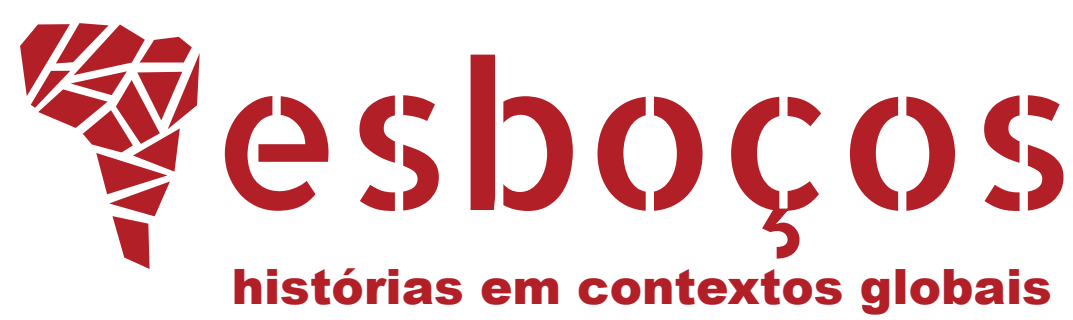

\title{
UTOPIA WITHOUT US?
}

Zoltán Boldizsár Simon ab (D) https://orcid.org/0000-0001-8763-7415 Email: zoltanbsimon@uni-bielefeld.de

a Bielefeld University, Faculty of History, Philosophy and Theology, Department of History, Bielefeld, Germany

${ }^{\mathrm{b}}$ Leiden University, Institute for History, Leiden, The Netherlands

\section{DEBATE}

Antropoceno, utopia e distopia 


\section{ABSTRACT}

As the prospect of self-authored human extinction increasingly appears as a plausible scenario of human futures, a growing number of efforts aim at comprehending it as the prospect of the world without us. Patrícia Vieira convincingly shows in her essay on utopia and dystopia in the Anthropocene that utopianism has become a prominent interpretive strategy to render the possibility of human extinction meaningful. This brief reflection argues against the feasibility of considering the world without us in utopian terms. It identifies three tacit assumptions in utopian interpretations of our disappearance: they (1) take for granted that prospects of human extinction and post-apocalyptic themes are of the same kind; (2) presume that the biological character of human extinction needs no special attention when situating it with the social character of utopian thinking; and (3) remain committed to an anthropocentric view in assuming that we are the ones to attribute meaning even to the world defined by our absence. In challenging these assumptions, the essay develops three theses on the relation of utopia and the prospect of the world without us.

\section{KEYWORDS}

Utopia. Human extinction. Anthropocene. 
an there be a utopia without us? Certainly, there can be a world without us, just as well as there was a world before us. Alan Weisman's The World without Us (2007) is arguably the best example of this. It turned the prospect of human extinction into the most powerful imaginary designed to help us better understand how we have been transforming the planet lately. The thought experiment to picture what happens to the planet and human-made artifacts after we disappear can be immensely stimulating. For one thing, it inspired Dipesh Chakrabarty (2009) to reflect on how the recognition that we are living in the Anthropocene (CRUTZEN, 2002; STEFFEN et al. 2011) - that is, living in the yet unformalized geological epoch when human activity transforms the Earth conceived of as a system of interacting physical and social processes - poses a challenge to historical thinking.

Linked with the Anthropocene, the world without us appears as a paradox. On the one hand, the world without us as an anthropocenic prospect depicts our nonexistence and absence as a plausible future scenario. On the other hand, human nonexistence is a result of our own activity; it is the prospect of an epoch that is literally about an overwhelming human existence and presence, with human capacities being elevated even to the level of a force of nature (with the anthropos of the Anthropocene meaning human in Greek). However, precisely because of its paradoxical nature, the world without us as an Anthropocene prospect is the most instrumental in confronting us with ourselves, our doings, our unprecedented powers, and our boundaries - all this at the same time.

With these complexities and intricacies in mind, let me rephrase the opening question in a slightly different way: is there any way in which the prospect of the world without us can be considered as utopian? This, I believe, is the most perplexing question posed by Patrícia Vieira's insightful essay "Utopia and Dystopia in the Age of the Anthropocene." In the coming pages, I hope to engage with this question and muse over the possibility of a utopian understanding of the world without us. Although I may end up sketching an answer other than the one she develops, I would like to use the words of Vieira as the point of departure (2020, p. 356), when she notes that utopian and dystopian thought was, up until our recent present, united in viewing "human disappearance from the face of Earth as an eminently negative development".

Vieira is right in suggesting that it is no longer self-evident that we view the prospect of human extinction in negative terms. And this, in fact, is not restricted to the Anthropocene context or to ecological and environmental futures. As Apolline Taillandier (2020) shows, advocates of technological futures of artificial general intelligence and superintelligence may consider human history as a transitional stage in a longer civilizational development tending towards forms of technological life. Remaining within the confines of modern modes of historical thinking and extending the idea of progress beyond the human world and at the expense of human life, technological futures can equally fuel an imagination that is no longer gloomy but sometimes even enthusiastic about the prospect of a world without us.

Yet there is a certain obscurity about the most decisive aspect of futures of human non-existence. For the possibility of viewing human extinction as something not negative does not necessarily mean viewing it as something positive, let alone, something utopian. There are degrees and shades in the recent upsurge of thinking about a world without us in terms other than negative, and it seems to me that sometimes Vieira herself is hesitant to attribute explicit utopianism to the very examples she is discussing. In commenting on the emergence of the practice of contemplating 
human extinction, Mark Jendrysik (2011) seems more determined in using utopia as an interpretive framework. Jendrysik argues that Weisman's The World without Us (2007) and the documentaries it inspired - Aftermath: Population Zero (2008) and Life after People (2008) - are representatives of a new kind of utopianism that finds reassurance in imagining a future in which human self-annihilation entails the rebirth of nature. The significance of the imaginary is provided by earlier visions of human extinction in which our premature self-destruction is accompanied by the destruction of nature. The new utopianism, according to Jendrysik, channels utopian motives into saving at least nature - even at the cost of our disappearance.

I think that Vieira's hesitation to fully give in to a utopianism of human nonexistence is well justified. When she asks at the end of her essay "What if we give hope a chance after all?" (VIEIRA, 2020, p. 362), she means that we should not dismiss scenarios of utopia that include humans. There is, however, another kind of hesitation apparent in Vieira's essay; one that is perhaps less deliberate. At one point, Vieira (2020, p. 358) affirms Jendrysik's views and states that "human society is deemed beyond repair and the only way of achieving utopian aspirations is to do away with Homo sapiens altogether." At another point, in analysing Margaret Atwood's MaddAddam trilogy $(2003,2009,2013)$ as her primary example, Vieira (2020, p. 360) nevertheless claims that when Atwood sees human extinction in terms other than catastrophic, it means that Atwood considers it "merely as one of the possible outcomes of our way of life, one of the possible answers to the question of Homo sapiens' future".

What Vieira seems to imply here is that the world without us, seen as a possible outcome in Atwood's trilogy, is neither utopian nor dystopian. And this is the point at which I would like steer the question raised by Vieira into a slightly different direction than she does. What I want to argue for is not that we should not give up on including humans in utopian scenarios; instead, I want to point out that inasmuch as we think in terms of utopia, we cannot but stick with humans and our human values included in one way or another. We either necessarily uphold utopias that include humans, or we contemplate a world without us that is, necessarily again, also a world without our values - including utopianism.

To get a better grasp of what this means, consider how the detachment Vieira attributes to Atwood does not indicate explicit utopianism due to the lack of value judgements in the prospect of the world without us. A utopian world is a world infused with our values. Utopianism would require an evaluative judgement of betterment in one way or another, regardless of how one defines utopia. Cases when the future without humans is pictured as idyllic may provide a firmer ground for considering them as explicitly utopian imaginaries. With a bit of a stretch, Weisman's book likely comes close to such an idyllic depiction, thanks to its vivid descriptions of how nature takes over the planet and humanmade things as soon as we no longer exist, which may indeed appear romanticized. Still, an idyllic future state does not necessarily imply utopian thinking, and in his essay on utopian prospects of human extinction Jendrysik (2011, p. 44) actually notes that "in the end Weisman tries to overcome the feeling that our end might be a good thing".

All in all, claims concerning the upsurge of a utopia without us seem a bit overstated. Interpretations that link human extinction and utopianism are most certainly right in calling attention to the increasing enthusiasm about contemplating human extinction in not necessarily negative terms. But sometimes they seem more eager to attribute a utopian character to prospects of a world without us than the imaginaries they interpret explicitly would. 
There are three profoundly interrelated premises at work when interpreting human extinction in utopian terms. Such utopian interpretations (1) take for granted that prospects of human extinction and post-apocalyptic themes are essentially of the same kind; (2) presume, consequently, that the peculiarly biological character of human extinction needs no special attention even when situating it with the peculiarly social character of utopian thinking; and (3) remain committed to an anthropocentric view in assuming that we are the ones vested with the capacity to attribute meaning even to the world defined by our absence. Although none of the three points are charges or accusations, I want to question them as the most profound and largely unexamined assumptions on which one can entertain the possibility of a utopia without us.

On the remaining pages, I will mostly - although not exclusively - argue for the opposite view: the impossibility of a utopia without us. In doing so, I will turn these assumptions upside down and shape them into three theses on the relation of utopia and the prospect of the world without us. Two and a half theses will concern the impossibility of a utopia without us, while half of the last thesis will be reserved to the costs of nonetheless projecting utopian thinking over the prospect of the world without us.

\section{THESIS 1: POST-APOCALYPTIC THEMES OF SOCIETAL COLLAPSE AND PROSPECTS OF HUMAN EXTINCTION ARE DIFFERENT IN KIND}

The world without us is typically considered to be utopian on the premise of a close affiliation between prospects of societal collapse and human extinction. As mentioned earlier, Jendrysik (2011) unpacks the latter as a variation of the betterknown theme of anthropogenic environmental catastrophe in which we bring an end to nature. By this logic, the significance of imagining human extinction is that it brings relief in assuring ourselves that nature survives us: instead of bringing nature down with us, our downfall means the rebirth of nature. Jendrysik measures Wiesman's nonfiction of human extinction and the documentaries it inspired to literary and cinematic representations of societal collapse, such as Atwood's MaddAddam trilogy, Cormac McCarthy's The Road (2006) or Pixar's Wall-E (2008). These are typically considered as belonging to the post-apocalyptic genre (HICKS, 2016; HORN, 2018), or to the more recently conceptualized climate fiction, cli-fi (WRIGHT, 2019).

In Vieira's analysis, discussions of cli-fi and post-apocalyptic novels and cinema are more explicitly merged with imaginaries of the world without us. Atwood's postapocalyptic trilogy with living and acting human characters - that is, strictly speaking, a world still with us - can become a core example of utopianism about a world without us by virtue of lacking a clear distinction between societal collapse and human extinction. And there is, in fact, nothing surprising in this. Even the newly developing expertise in threats to humanity - booming after John Leslie's The End of the World: The Science and Ethics of Human Extinction (1996) - tends to conflate the two. To begin with, the definition of "existential risk" as "one where an adverse outcome would either annihilate Earth-originating intelligent life or permanently and drastically curtail its potential" (BOSTROM, 2002) does not distinguish categorically between the two prospects. Even today, the opening page of the website of The Centre for the Study of Existential Risk at the University of Cambridge defines its mission along similar lines by stating that "we 
are dedicated to the study and mitigation of risks that could lead to human extinction or civilizational collapse". ${ }^{1}$ The phrasing of either-or - both in Bostrom's definition and in the mission statement of The Centre for the Study of Existential Risk - hints only at a difference of degree, in which there is the worst case scenario of human extinction and the second worst case scenario of "almost".

This is not to say that there are no good reasons for discussing the two prospects together. For one thing, they both appear as threatening for humans. Inasmuch as the aim is to sustain human flourishing, the typical undesirability of both societal collapse and human extinction - despite some counterexamples such as the Voluntary Human Extinction Movement - is indeed a reasonable justification for bringing them together. ${ }^{2}$ What I want to point out is only that, with respect to their very fundamental constitution, the two prospects could not look more substantially distinct.

Plainly put, the categorial distinction between prospects of societal collapse and human extinction is that between human existence and human non-existence. As long as there is but one human being roaming the Earth, surviving underground, or being evacuated to another planet, the prospect is just as well about human existence as any other visions of the future are, be they shiny or gloomy. As long as there is but one human survivor, the story will inevitably be about the fate of human characters or about the fate of humanity as such. Hence the fact that Wall-E ends on the note of humans returning to Earth (centuries after the human evacuation of the planet). Contrary to this, in prospects of human nonexistence, the fate of humanity is already decided. The only open question concerns what comes after, what comes in the world after us, what comes next in the world without us. Can it be utopia?

\section{THESIS 2: HUMAN EXTINCTION CONCERNS US AS BIOLOGICAL BEINGS}

The answer to the question of whether the world without us - as the world after us - can be utopian depends less on how exactly one defines utopia and more on grasping the radicality of the image of the world without us. As to the former, Vieira's essay wonderfully captures the difficulties of defining utopia and maintaining utopianism today. Despite all difficulties, however, there is something that nevertheless seems integral to all kinds of temporal utopias and utopianisms, something that is integral to all modern utopias that moved their vision of betterment from the early modern spatial realm of distant places to the temporal realm of the future (KOSELLECK, 2002). It is the scope of their better futures: the socio-political domain.

At the centre of modern utopian thinking is the human as a social being, aiming at socio-political betterment over time. This remains true of even those concepts of utopia that deliberately intend to abstain from the inheritance of modernist assumptions, such as the notion of "existential utopia" that Vieira and Michael Marder advocate. In hoping to open the possibility of betterment over time as springing out of the actual instead of invoking metaphysical thinking, "existential utopia" assumes that at stake is the "very

\footnotetext{
${ }^{1}$ https://www.cser.ac.uk/.

2 http://vhemt.org/.
} 
survival" of utopia "as a pertinent category for social and political change" (MARDER; VIEIRA, 2011, p. xiii).

Contrary to this, prospects of human extinction in the Anthropocene are devoid of social content and concern the biological dying out of the human as a species. Remember the distinction introduced in the first thesis. The societal collapse of cli-fi and post-apocalyptic literature and cinema, due to its eventual focus on the fate of human characters or humanity as such, necessarily retains its social understanding of the human at least to an extent. It typically blends the social and the biological, depending on the severity of the existential threat. In the prospect of a world without us, however, there is no longer space for concerns we associate with intra-human relations and with the socio-political domain.

Dipesh Chakrabarty (2009, p. 212-220) realized in his first engagement with the Anthropocene that it demands historical studies in particular and human and social scientific knowledge in general to engage with species thinking - an idea that has its own history in biological thought (WILKINS, 2009). Chakrabarty was even aware that species thinking goes against the sensitivities of scholars of the human world, developed against the backdrop of past political misuses of a biological understanding of human beings. The eugenic enterprise, which, as Marius Turda (2010) argues, was integral even to the social project of modernity, is likely the most well-known of such past political misuses. But there are ways in which contemporary biological understandings of humans are even more imminently prone to potential political abuse. Just think about the manipulation and engineering of our "vital capacities" on the molecular and genomic levels that Nikolas Rose (2007) pictures as our recent "politics of life itself." Although suspicions may reasonably arise about such developments, Rose (2007, p. 8) does not interpret them as "the rise of a new biological and genetic determinism," but as "the emergence of a new somatic ethics". The case is not that we replace a social understanding of the human with a biological understanding in a purely biological biopolitics fuelled by technoscientific developments. Instead, the case is that that social and biological understandings of the human intertwine today in a new constellation in which humans appear as "biocultural creatures" (FROST, 2016).

Similarly, the Anthropocene challenge is not about overwriting concerns for the social world and a social understanding of the human with biological concerns and a biological understanding of the human. It is rather the demand to think on different scales - that of the social scale of the human world and that of the species scale of the natural world - and situate the collision of scales, that is, the collision of the human and the natural worlds in a meaningful way. For history, this means nothing other than the task of writing human and natural histories, and, consequently, the task of "thinking simultaneously on both registers, to mix together the immiscible chronologies of capital and species history" (CHAKRABARTY, 2009, p. 220).

The point I hope to prove by invoking Chakrabarty's endeavour is not only that the Anthropocene challenge involves a species understanding of the human, but that social and biological understandings are both implied insofar as the Anthropocene prospect is milder than full-blown human extinction. Inasmuch as the aim is to maintain human existence, and inasmuch as we try to make sense of ourselves and a world that includes us, we necessarily think with both the social and the biological.

But as soon as we imagine a world without us, as soon as we contemplate human extinction, we begin to think in terms of our biological dying out and we imagine a world from which we biologically disappear. Surely, from the present point of view, 
we consider this in terms of values and value judgments. As Vieira (2020, p. 355) perceptively notes, the novelty in this respect is that "it is not so much that we fail to conjure up a good society but, rather, that we are unsure as to whether human society as such is a good thing". What this means is that the value judgment and the social aspect is still present - but only in the present. Because, by this logic, social betterment, somewhat paradoxically, appears as the end of the social. And the end of the social, by entailment, spells the end of values and thus the end of utopia, meaning that, ultimately, the future in which humans are absent is not the future of utopia but the future of its absence.

The biological disappearance of humans rather evidently entails the disappearance of the values associated with social, cultural, and political modes of human existence, and the latter happens because the former does. This is the sense in which the prospect of human extinction is primarily concerned with what we understand as a biological species. And if extinction happens and the world without us comes into being, that world will be neither human, nor biocultural in our very human understanding; it will simply be indifferent to our categories. So, to ask the question for the last time: can that prospect of a world indifferent to us and our values nevertheless be utopian?

\section{THESIS 3: WE EITHER CONSIDER HUMAN EXTINCTION AS A PROSPECT DEVOID OF UTOPIANISM AND THUS WE CONSIDER IT AS VALUE-FREE, OR WE PROJECT OUR UTOPIAN VALUES OVER THE PROSPECT OF THE WORLD AND THUS WE LEVEL UP OUR ANTHROPOCENTRISM}

Let me begin with the first half of this third thesis. It is the default option that follows from the two preceding theses. It states that, in principle, the prospect of human extinction cannot be utopian. For it is simply the prospect of the end of the social world, the end of the social understanding of the human, and the end of human values. Our values, our social imaginaries, and our utopian drives die out with our biological dying out.

As the future without us is a future without social content and without our values, it can hardly be considered in terms attuned to capturing a social constitution. The world without us, in that respect, is just like the world before us. The same way we tend to think of the latter as the pre-social world, we should think of the former as a post-social one, while both are simply non-social worlds. It may very well be that some of us think about a pre-social world nostalgically in idyllic terms, and so the post-social world may appear the same. But precisely because they belong to the same family, the post-social world defies utopianism just as much as the pre-social one. The same way that we do not think of pre-social idyllic fantasies as utopian but as nostalgic, we have no reasons to think of post-social imaginaries is such terms. At best, they appear as objects of nostalgia projected to the future.

Yet there may be a crucial difference between the pre-social and the post-social. Unlike in the pre-social past, the material remains of human societies will be part of the post-social future, up to certain points of various timelines, indicating a world that was once a social one. But to whom exactly is the previous existence of a social world 
indicated? For us in the present until we still exist, but certainly not to the inhabitants of the natural world without us as we imagine it (and, for a moment, let's bracket how humans are part of the "100 Percent-Natural Club," as Timothy LeCain (2017) likes to phrase it). In the absence of the societies and the social beings that produced those remains and would be able to recognize them as such, they will simply form the natural world just like everything else.

That's about the rather straightforward first half of the answer. The second half is far more ambivalent. For even if there is no reason to think about human extinction on the basis of our existing notions of utopia, nothing prevents anyone from filling the prospect of the world without us with social content and values. I cannot prevent it even if I wanted to. Nor will the future of human extinction protest, being short of beings, who, to our current knowledge, would comprehend utopian values.

In defence of viewing human extinction as utopian, one can argue that, from our present point of view, being embedded in social worlds of value judgements, we typically look at the future in terms of values, regardless of what futures we imagine. We only need to extend the scope of our existing notions of utopia and value judgement and ask the question of whether, as Vieira put it, human societies as such are good. One could argue that the distinctive features of a new kind of (what can be called) extinction-utopia is precisely that it escapes the socio-political domain: when the whole idea of socio-political betterment is compromised, the only betterment option left is to do away with the societal once and for all.

To avoid misunderstandings, I do not wish to advocate these views. But their actual existence needs to be noted, despite the fact of devoting this essay to an argument aiming to show that such views are illogical and self-contradictory. To be as clear as possible, my view is that Anthropocene prospects of both societal collapse and human extinction belong to the category of what I call "posthistorical dystopia" (SIMON, 2019 , p. 93-103), that is, the prospect of an immense transformation that is no longer "historical" in the sense modern societies typically thought about change over time. Such prospects are posthistorical inasmuch as they are expected to be brought about by the outburst of a transformative event, instead of arriving at them over the course of a developmental historical process, be that development considered to be progressive or regressive. As to their dystopian character, the evental transformation they trigger are inherently dystopian inasmuch as the change they entail are cognitively inaccessible to human beings. I call the type of change "unprecedented change" (SIMON, 2019), and the event that triggers such change an "epochal event" (SIMON, 2020).

Even today's science is informed by such structural expectations of immense transformative changes. If we turn from literary and cinematic imaginaries to what Earth system science says, then we are left without vivid descriptions and with far more uncertainties. We invest less in picturing post-apocalyptic circumstances and more in conceding that we have no concrete idea about what follows once the Earth system is being pushed beyond "tipping points" (LENTON, 2011) and crosses "planetary boundaries" (ROCKSTRÖM et al., 2009), abruptly transitioning to conditions we cannot fathom. In my view, it is the very unfathomability and cognitive inaccessibility that necessarily renders our recent visions of the future inherently dystopian (even those with utopian content such as transhumanism).

The above full disclosure is necessary for addressing the last inconsistency one can detect in utopian interpretations of the world without us. To make the selfcontradictory nature of a utopia without us visible, I want to measure it against 
posthistorical dystopia with respect to their ultimate concerns. On the one side, considering Anthropocene futures in terms of posthistorical dystopia means that the prospects are ours in the sense that they are concerned with the fate of humanity. On the other, seeing the world without us as utopian is concerned with the fate of the planet, after the fate of humanity is settled. Whereas the former view clearly and admittedly retains an extent of human-centeredness, in the case of the latter the question arises: whose utopia would that be, then?

Despite being human prospects, extinction-utopias aim at a viewpoint that escapes human-centeredness. They appeal to a planetary point of view instead, with a broadly defined "life" at their centre. The world without us appears as utopian because it claims to occupy the hypothetical viewpoint of the entirety of the natural world and the greater planetary scheme of "life" that the particular human lifeforms only seem to damage. Either accidentally or deliberately, this appeal coincides with the current trend in the humanities and the social sciences to develop post- anti- and non-anthropocentric views (CRIST; KOPNINA, 2014; DOMANSKA, 2019) that intend to overcome ideas of human exceptionalism and the view that the human lifeform is superior to other lifeforms.

That said, the utmost irony of projecting utopianism over the prospect of the world without us is precisely that it is profoundly anthropocentric in another sense. Perhaps even more anthropocentric than the admittedly human-centered view that attempts to avoid human extinction. Without arguing either for or against anthropocentrism, the only thing I wish to point out is that utopianism about human extinction scales up our anthropocentric drive in defining even the world of human non-existence in terms of our very human values. In other words, the prospect of a utopia without us appeals to become a non-anthropocentric worldview on the profoundly anthropocentric assumption of retaining a human superiority in investing the world with meaning even for the world characterized by the absence of humans. It conveys the sense that we know better - or perhaps that we simply know the best - about what's good for other lifeforms of the planet, for the planet itself, and, well, perhaps even for the universe (by entailment). In the guise of non-anthropocentrism, we get intensified anthropocentrism.

All in all, the final answer to the question whether there can be a utopia without us is as follows: no, not in the sense of our existing notions of utopia. Although the possibility of redefining the term and extending its scope can be retained, extinctionutopianism defies its own premises by scaling up human exceptionalism and reinforcing the very attitudes it intends to overcome.

\section{REFERENCES}

Aftermath: Population Zero. [Film] Dir. Christopher Rowley. National Geographic, 2008.

ATWOOD, Margaret. Oryx and Crake. New York: Anchor Books, 2003.

ATWOOD, Margaret. The Year of the Flood. New York: Anchor Books, 2009.

ATWOOD, Margaret. MaddAddam. New York: Anchor Books, 2013. 
BOSTROM, Nick. Existential Risk: Analyzing Human Extinction Scenarios and Related Hazards. Journal of Evolution and Technology, Willington, v. 9, 2002. Available at: https://www.jetpress.org/volume9/risks.html.

CHAKRABARTY, Dipesh. The Climate of History: Four Theses. Critical Inquiry, Chicago, v. 35, n. 2, p. 197-222, 2009.

CRIST, Eileen; KOPNINA, Helen. Unsettling Anthropocentrism. Dialectical Anthropology, Amsterdam, v. 38, n. 4, p. 387-396, 2014.

CRUTZEN, Paul J. Geology of Mankind. Nature, London, v. 415, n. 23, 2002.

DOMANSKA, Ewa. Posthumanist History. In: TAMM, Marek; BURKE, Peter (ed.). Debating New Approaches to History. London: Bloomsbury, 2018. p. 327-338.

FROST, Samantha. Biocultural Creatures: Toward a New Theory of the Human. Durham: Duke University Press, 2016.

HICKS, Heather J. The Post-Apocalyptic Novel in the Twenty-First Century: Modernity beyond Salvage. Basingstoke: Palgrave, 2016.

HORN, Eva. The Future as Catastrophe: Imagining Disaster in the Modern Age. Trans. Valentine A. Pakis. New York: Columbia University Press, 2018.

JENDRYSIK, Mark S. Back to the Garden: New Visions of Posthuman Futures. Utopian Studies, Lanham, v. 22, n. 1, p. 34-51, 2011.

KOSELLECK, Reinhart. The Temporalization of Utopia. In: KOSELLECK, Reinhart. The Practice of Conceptual History: Timing History, Spacing Concepts. Trans. Todd Samuel Presner and Others. Stanford: Stanford University Press, 2002. p. 84-99.

LECAIN, Timothy J. The Matter of History: How Things Create the Past. Cambridge: Cambridge University Press, 2017.

LENTON, Timothy M. Early Warning of Climate Tipping Points. Nature Climate Change, London, v. 1, p. 201-209, 2011.

LESLIE, John. The End of the World: The Science and Ethics of Human Extinction. London: Routledge, 1996.

Life after People. [Film] Dir. David de Vries. History Channel, 2008.

McCARTHY, Cormac. The Road. New York: Alfred A. Knopf, 2006.

ROCKSTRÖM, Johan et al. Planetary Boundaries: Exploring the Safe Operating Space for Humanity. Ecology and Society, London, v. 14, n. 2, art. 32, 2009. 
ROSE, Nikolas. The Politics of Life Itself: Biomedicine, Power, and Subjectivity in the Twenty-First Century. Princeton: Princeton University Press, 2007.

SIMON, Zoltán Boldizsár. History in Times of Unprecedented Change: A Theory for the $21^{\text {st }}$ Century. London: Bloomsbury, 2019.

SIMON, Zoltán Boldizsár. The Epochal Event: Transformations in the Entangled Human, Technological, and Natural Worlds. Cham: Palgrave. 2020.

STEFFEN, Will et al. The Anthropocene: Conceptual and Historical Perspectives.

Philosophical Transactions of the Royal Society A, London, v. 369, p. 842-867, 2011.

TAILLANDIER, Apolline. Now for the Long Term: Posthuman Futures and the Limits of the Political. Dissertation. Paris: MaxPo, 2020.

TURDA, Marius. Modernism and Eugenics. Basingstoke: Palgrave, 2010.

MARDER, Michael; VIEIRA, Patrícia. Utopia: A Political Ontology. In: VIEIRA, Patrícia; MARDER, Michael (ed.). Existential Utopia: New Perspectives on Utopian Thought. New York: Continuum, 2012, p. ix-xv.

VIEIRA, Patrícia. Utopia and Dystopia in the Age of the Anthropocene. Esboços, Florianópolis, v. 27, n. 46, p. 350-365, 2020.

Wall-E. [Film] Dir. Andrew Stanton. Pixar Animation Studios, 2008.

WEISMAN, Alan. The World without Us. New York: Thomas Dunne Books, 2007.

WILKINS, John S. Species: A History of the Idea. Berkeley: University of California Press, 2009.

WRIGHT, Laura. Cli-Fi: Environmental Literature for the Anthropocene. In: BAUMBACH, Sibylle; NEUMANN, Brigit (ed.). New Approaches to the Twenty-FirstCentury Anglophone Novel. Cham: Palgrave, 2019. p. 99-116.

\section{NOTES}

\section{AUTHOR DETAILS}

Zoltán Boldizsár Simon: PhD. Research fellow, Bielefeld University, Faculty of History, Philosophy and Theology, Department of History, Bielefeld, Germany. Assistant professor, Leiden University, Institute for History, Leiden, Netherlands.

\section{CORRESPONDING ADDRESS}

Universitätsstraße 25, 33615, Bielefeld, Germany.

\section{ACKNOWLEDGEMENTS}

I thank Sinmi Akin-Aina for helping with the read-though and language editing. 


\section{FUNDING}

Not applicable.

\section{ETHICS COMMITTEE APPROVAL}

Not applicable.

\section{CONFLICT OF INTEREST}

There is no conflict of interest.

\section{LICENSE OF USE}

This article is licensed under the Creative Commons License CC-BY. With this license, you can share, adapt, create for any purpose, as long as the authorship is properly attributed.

\section{PUBLISHER}

Universidade Federal de Santa Catarina. Graduate Program in History. UFSC Journal Portal. The ideas expressed in this article are the sole responsibility of its authors, and do not represent, necessarily, the opinion of the editors or the University.

\section{EDITORS}

Fábio Augusto Morales

Flávia Florentino Varella (Editor-in-chief)

\section{HISTORY}

Received on: Mar. 272020

Approved on: Jul. 282020

How to cite: SIMON, Zoltán Boldizsár. Utopia without us?. Esboços, Florianópolis, v. 27, n. 46, p. 377-389, set./dez. 2020. 